\title{
Competences for Strengthening Entrepreneurial Capabilities in Europe
}

\author{
Tatjana N̦ikitina ${ }^{1, *}$, Inga Lapina ${ }^{1}$ (), Modris Ozolin, š ${ }^{1}$, Madara Mara Irbe ${ }^{1}$, Martijn Priem ${ }^{2}$, \\ Matthijs Smits ${ }^{2}$ and Mikhail Nemilentsev ${ }^{3}$ \\ 1 Faculty of Engineering Economics and Management, Riga Technical University, Kalnciema iela 6, \\ LV-1048 Riga, Latvia; inga.lapina@rtu.lv (I.L.); modris.ozolins@rtu.lv (M.O.); \\ madara-mara.irbe@rtu.lv (M.M.I.) \\ 2 Business School, Rotterdam University of Applied Sciences, P.O. Box 25035, \\ 3001 HA Rotterdam, The Netherlands; m.priem@hr.nl (M.P.); m.smits@hr.nl (M.S.) \\ 3 Department of International Business, South-Eastern Finland University of Applied Sciences, Paraatikenttä 7, \\ 45100 Kouvola, Finland; mikhail.nemilentsev@xamk.fi \\ * Correspondence: tatjana.nikitina@edu.rtu.lv
}

Received: 17 June 2020; Accepted: 31 July 2020; Published: 5 August 2020

\begin{abstract}
Authors in previous studies pointed out that the professional competences of managers overlap with the competences and skills that are attributed to entrepreneurs. The goal of this study is to analyze the correlation between the actual market demand for competences to develop new businesses and the competence of training and development by higher education institutions (HEIs) and business supporting institutions (BSIs). The research question is "Are the entrepreneurial competences demanded by the domestic markets in Finland, Latvia and The Netherlands aligned with the entrepreneurship educational and business supporting policies?" As a research methodology, we chose focus groups and semi-structured interviews conducted for start-up entrepreneurs, HEIs, and BSIs as methods for data gathering. An importance-performance analysis (IPA) was applied as the method for data analysis. As the main research results, the authors identified that ethical and sustainable thinking as well financial and economic literacy were considered to be the least important competences, while motivation and perseverance were commonly ranked as highly important by entrepreneurs in all the countries studied. Entrepreneurship education policy in The Netherlands is fully harmonized with market demand. Entrepreneurship development activities in Finland also meet the market's needs, however HEIs and BSIs could develop self-awareness and self-efficacy as well as cope with uncertainty, ambiguity and risk competences. The major disagreement was detected between entrepreneurs' expectations and entrepreneurship education activities conducted by HEIs and BSIs in Latvia. This research implication fills the gap in knowledge about the entrepreneurial competences developed by HEIs and BSIs and were demanded (considered as important) by the market in the researched countries. Further, we developed the entrepreneurship training methodology for transdisciplinary students to enhance entrepreneurial competence dissemination and development across education programs and beyond.
\end{abstract}

Keywords: competence; managerial competences; entrepreneurial competences; business supporting institutions (BSIs); higher education institutions (HEIs)

\section{Introduction}

Researchers recently uncovered that the professional competences of managers overlap with the competences and skills that are attributed to entrepreneurs [1,2]. At the same time, policy makers and other researchers report the demand for entrepreneurial behavior to be exhibited by employees, 
assuming such actions as a key driver for sustainable employability during constant changes [3]. While there are different opinions among researchers about the duplication of managerial and entrepreneurial competences, over the last few decades a noticeable increase in the number of small and medium enterprises (SME), where managers perform entrepreneurial, managerial and operational functions simultaneously, was observed [4-6]. The researchers assumed that entrepreneurs are more skilled than managers due to their interchanging roles as managers, owners and entrepreneurs. Researchers have identified a specific group of competences that are required to start and manage small businesses while responding to its specific challenges [7-9]. Another discovery was that the earliest life cycle stage of an entity requires a different set of abilities, in comparison to later stages [10].

More and more researchers today are interested in exploring the field of the development of entrepreneurial knowledge, skill sets and competences that are required for the successful launch and management of a firm. Mitchelmore and Rowley [11] propose a list of key competences, including 50 entrepreneurial skills, business and management skills, human relations skills, conceptual and relationship skills, as well as attitude or feature skills. Lans et al. [12] describe the following five generic competencies: opportunity competence, social competence, business competence, industry-specific competence, and self-efficacy. Addressing sustainability issues, Dentoni et al. [13] developed a framework consisting of seven competencies: systems-thinking competence, foresight-thinking competence, normative competence, embracing diversity and interdisciplinary, interpersonal competence, action competence, and strategic management.

The number of companies that belong to the segment of small and medium enterprises (SMEs) is rising over the globe, and academia is concerned about proper formal and informal education methods to train and assess the competences adapted to real business environments [14]. For example, in the EU, SME companies account for $93 \%$ of all registered enterprises [15], while in Russia, the figure is even greater at 95.5\% [16]; it is 97\% in China [17] and 99.8\% in Lithuania [18]. There were more than 25 million SMEs in the EU-28 (2018). SMEs accounted for $99.8 \%$ of all enterprises in the EU-28's non-financial business sector, producing $56.4 \%$ of value added and $66.6 \%$ of employment [19]. The European Commission considers SMEs and entrepreneurship as key to ensuring economic growth, innovation, employment, and social integration in the EU.

When reviewing articles in Scopus, Web of Science, and EBSCO databases for the last three years, the authors observed that the major part of the entrepreneurship-related articles are devoted to case studies and programs aimed at developing entrepreneurial competences in universities. Researchers are convinced that curricular and extracurricular activities are focused on providing the necessary knowledge to start a business, including legal instructions to an entrepreneurial venture [20], developing a competence to spot and exploit a business opportunity, as well as increasing awareness and motivation in HEIs to form favorable conditions and a favorable culture to develop entrepreneurship intentions in students, and to influence self-efficacy and social norms [21-24]. It is worth mentioning that a one-year course is not the sole option that HEIs could offer to students. Rather, short three or four-day workshops and summer school programs have become popular extracurricular activities in European HEIs [25].

There is another promising direction in education activities. This is the emphasis on entrepreneurial activities for students in technical discipline programs by means of creating an interdisciplinary course on the basics of entrepreneurial skills, covering economic, managerial, social science aspects of a problem and its subsequent pilot implementation. The outcome of the approach is the expectation that students will be aware of the business environment and will be able to apply the skills in practice [26,27]. However, despite the benefits of the cross-disciplinary approach, its application has not become a standard yet [28].

Apart from that, another researcher has found a positive correlation between entrepreneurial competence development and digital skills used for learning and new knowledge creation [29]. Business simulations remain among the most efficient tools for developing critical thinking and a deeper understanding of the essence of entrepreneurship [27,30]. In more sophisticated cases, 
the young generation demands in-depth development of entrepreneurial marketing skills for students who work and study within the entrepreneurial teams, e.g., in 2018, Petrylaite [31] explored a case of an SME marketing model application within higher education entrepreneurial teams. The creation of the business plan was a highly-rated activity that empowered the students' entrepreneurial competence [32].

Changes in education programs not only affect students but also the faculty, as a shift in the teaching paradigm is the basis for developing the entrepreneurial competences of its lecturers via interactive workshops and hands-on exercises [33]. Many HEIs foster their own entrepreneurial ecosystems by re-mastering their study programs and conducting projects that include students, academic staff and business representatives [34-39]. The ecosystem drivers are "teacherpreneurs", who blend risk-taking and entrepreneurial leadership with the culture of creativity and reflection [40], as well as university-based ventures that are the basis for students' business plan contests and their implementation [41]. When exploring different incubation modes, some researchers identified barriers and gateways to digital enterprises [42].

Despite all the above-mentioned initiatives, it is worth noting that some researchers still discover a difference between men and women in the case of entrepreneurship propensity, and due to many factors, male students choose to become entrepreneurs much more often than females [43]. However, the gender bias effect is less strong in the cases of potential successors of family business enterprises [44], which is probably due to the strong support of the senior generation [45].

When investigating organizational practices in increasing the probability of a successful start of a modern enterprise and its evolution, researchers mentioned the role of organizational agility as an ability to respond to changes quickly in rapidly changing environments, and information communication technology (ICT) competence as potential accelerators that convert entrepreneurial knowledge into an innovative product [46,47], as well as the ability to cope with the "liability of newness" [48]. Start-ups as a new form of SMEs that boost entrepreneurial potential usually represent an interdisciplinary team composition, hence researchers have spotted the positive influences of multiple cross-disciplinarity toward the development of entrepreneurial capital [49], which is a function of entrepreneurial competences and entrepreneurial commitment [50]. More recent studies reported the crucial role of transformational leadership, entrepreneurial competence, technical competence and innovativeness as core to owner-managed SMEs [51]. It is worth mentioning that researchers found coaching to be an instrument for entrepreneurs' support in leadership development and new idea implementation [52].

While many research efforts have been spent to define and classify distinct features of the start-up phenomenon, no unified understanding has been achieved so far. There are differences in the perception and description of start-ups among academics, investors, government and regulative institutions, business support institutions and business people [53,54]. In our research, we consider start-ups as the early stage of business development until the "Go-Go" stage of the Adizes Corporate Lifecycle model [55].

To fill the gap in knowledge about entrepreneurial competences taught (performed) by HEIs and graduates' competence demanded (considered as important) by the market, we aim to bridge business education and supporting organizations with start-up entrepreneurs' needs by elaborating on the competences required for training and development. The output of the focus groups, interviews, and IPA analysis will be useful for developing the entrepreneurship training methodology for transdisciplinary students to enhance entrepreneurial competence dissemination and development across education programs and beyond.

This paper contains a description of the EntreComp competence framework and focus group orchestration, which was chosen as the methodology of the research. The results on the importance of competence for entrepreneurs and the level of performance of competence by HEIs and BSIs, as well as the importance performance analysis of the investigated competences, are presented for each of the 
researched countries separately. The Conclusion and Discussions Sections summarize the findings and link them to previous studies. The Reference Section lists 85 articles mentioned in the paper.

\section{Materials and Methods}

The purpose of this study was to analyze the correlation between the actual market demand for competences to launch and develop new businesses until the point of conditional balance, between control and flexibility in the entity and competence training in higher education institutions and business supporting institutions. The main research question was: Are the entrepreneurial competences demanded by the domestic markets in Finland, Latvia, and The Netherlands aligned with the entrepreneurship educational and business supporting policies?

The studies were performed as part of the ERASMUS+ KA2 Strategic partnership project "European Entrepreneurship Training Community", where the Entrepreneurship Competence Framework "EntreComp" was chosen as a benchmark for the assessment of emerging and demanded skills in the labor market. EntreComp is an entrepreneurial competence model developed in response to 'A New Skills Agenda for Europe: Working together to strengthen human capital, employability and competitiveness' by the European Commission. It describes entrepreneurship as a transversal competence that can be applied by citizens to all spheres of life, from nurturing personal development, to actively participating in society and (re)entering the job market as an employee or as a self-employed person, and to starting up ventures (cultural, social or commercial). It is made up of three competence areas: 'Ideas and opportunities', 'Resources' and 'Into action'. Each area includes five competences, which together are the building blocks of entrepreneurship as a competence [56,57].

The geographic scope of the project was Finland, Latvia, and The Netherlands. The project defined the focus groups as a methodological approach from at least five entrepreneurs in each of the project countries. We applied the focus group method as the major method for the first phase of the research to determine the demanded competences for start-ups. The focus group method was chosen for its highly interactive and dynamic character. The diversity of opinions in the focus groups led to a more creative and productive discussion. Carson et al. [58] indicated that "Focus groups concentrate clearly on a specific topic and involve interactive discussion among its participants."

The focus group was composed of start-up entrepreneurs. Entrepreneurs were carefully selected based on their entrepreneurial growth experience and involvement in the national entrepreneurship ecosystem of the country. They were also associated with a business supporting institution, i.e., a business incubator or accelerator, they collaborated with a higher education institution that is a partner of the project, and had launched at least two successful business enterprises.

The focus group activity was carried out in three corresponding steps: (1) brainstorming to generate entrepreneurship competences that are necessary at the early stage of business concept development until the "Go-Go" stage of the Adizes Corporate Lifecycle model [55], (2) identifying which of the generated competences are listed in the EntreComp model and which are new, and (3) evaluating the importance of the existing 15 EntreComp competences and of newly identified competences. The Adizes Corporate Lifecycle model provides a comprehensive explanation of the events during the lifecycle of an entity. There are ten stages in the lifetime of an entity, and the beginning is recognized at the very early stage of an idea or dream, called "Courtship" by I. Adizes. The second stage is "Infancy", where the founders build the company on the initial operating capital and the team strives to gain stability in cash flow and business operations. Companies at the third stage "Go-Go" have gained recognition, demand for their product and/or service, and sound cash flow. The next stages of the Adizes Corporate Lifecycle model explain the events that can lead to falling and the death of a company. However, the focus of the entrepreneurship training methodology within this project was limited to the first three stages of the model. Each of the Adizes Corporate Lifecycle stages requires a different set of entrepreneurial competences that are built on a set of fundamental and theoretic skills and knowledge, which in turn result in competences through experience, trial and error, failure or success. These competences can be gained in various ways during different periods of a person's lifecycle. However, an effective 
means of attaining entrepreneurial success is via higher education which develops a comprehensive understanding of entrepreneurship, offers a 'sandbox' for trial and error, and develops a vast set of skills to enable the acquisition of important entrepreneurial competences. Important competences are listed in EntreComp, which is the Entrepreneurship Competence Framework described later.

The evaluation of the importance of entrepreneurship competences was derived from the focus group activity and resulted in the first half of the importance-performance analysis (IPA). IPA is another methodological approach that is defined by the project of evaluating the effectiveness of the entrepreneurship training methodology during its approbation in higher education institutions in the three project countries-Finland, Latvia and The Netherlands-and in turn to compare these results with those that are gained through the research done in this article. The aim of IPA is to identify competences to be developed in students in the project partner institutions applying the transdisciplinary entrepreneurship training methodology. During the second phase of the research, semi-structured interviewing of representatives of HEIs and BSIs was applied for collection and processing of information. The aim of interviewing higher education institution representatives, including study program management and faculty, was to understand the best entrepreneurship training methodology they practice. The aim of interviewing entrepreneurship supporting institutions was to understand which entrepreneurship training activities were carried out at various levels of business idea development, i.e., pre-incubation, incubation and acceleration phase. Both latter activities also measured the performance levels of training the previously identified entrepreneurship competences.

The activities resulted in a comprehensive importance-performance analysis (IPA) to investigate the relationship between the importance of the competences required by the market and the quality, or performance, of the competences that are developed by higher education and business supportive institutions. The respondents of the focus groups represented the start-up entrepreneurs of the entrepreneurship ecosystem of the project partner institutions as they were involved in concurrent activities that were focused on developing the preliminary entrepreneurial competences in the future start-up entrepreneurs-students and participants of business supporting institution activities. Given their involvement, as well as their experience in transforming an idea into a start-up and subsequently into a prosperous enterprise, the respondents measured the level of importance of the EntreComp competences until the "Go-Go" stage of the Adizes Corporate Lifecycle model. As a secondary beneficial outcome of the investigation, the inquirers identified the best practices in various HEIs and BSIs of the partners' countries that foster entrepreneurial skills that are not covered by the scope of the article. Limitations of the research include its focus on the competence assessment performed in Finland, Latvia and The Netherlands, particularly around the entrepreneurship ecosystems of the project partner institutions, and the sample size of the respondents that represent these ecosystems through their level of involvement, the observations could therefore not be generalized for all European countries.

The authors applied the IPA method to analyze and visually represent inputs from both respondent groups: entrepreneurs and institutions that train students for entrepreneurship-HEIs and BSIs. IPA is a technique that visualizes four quadrants based on the values of importance and performance of different elements, which are calculated in relation to each other on a two-dimensional coordinate system. Based on the instruction given by the authors of the method, the values of different attributes were provided by respondents' assessment and were calculated and represented in the coordinate system where the horizontal axis was considered to be performance and the vertical axis was considered to be importance $[59,60]$. Importance and performance ratings were displayed on a two-dimensional grid, and fell into one of four quadrants- "Keep up the good work", "Potential overkill", "Low priority", and "Concentrate here". Conducting focus groups formed from start-up entrepreneurs, the authors asked the respondents in each country to evaluate the competences listed in the EntreComp Framework on a scale from 1 to 4 , where 1 is the least important competence necessary to start a business activity. The same grid was applied in the second phase when the authors asked BSIs and HEIs to evaluate the performance level of the EntreComp competences that were developed through their training 
activities in the institutions. The traditional visualization of IPA resulted in the form of quadrants and allowed the researchers to assess both performance and the importance of the competences, where "Concentrate here" (High Importance/Low Performance) quadrant presents the most significant discrepancy between importance and performance and hereafter translates discrepancy in expectations of the market players and education and business supporting institutions; the "Keep up the good work" (High Importance/High Performance) section covers the competences that are trained sufficiently and fully satisfy the market needs, the "Low priority" (Low Importance/Low Performance) part of the IPA quadrant represents the competences that are considered as not important by the market players, and the "Possible Overkill" (Low Importance/High Performance) section contains the competences that are properly trained by HEIs and BSIs, but are not demanded by the market. Overall, the IPA method was used to assess entrepreneurs' perception about the importance and performance of competence development by educational and business supporting institutions in the countries studied.

According to the EntreComp Framework [57], 15 entrepreneurial competences are divided into three areas. They are: (1) ideas and opportunities, (2) resources, and (3) into action, where the first area covers such competences as creativity, spotting opportunities and making the most of the ideas; the second area is related to the ability to stay focused and not give up, as well as gather resources and mobilize others, and the third area covers the ability to work with others, taking the initiative, and learning by doing. The full list of competences is shown in Table 1 and the concept was assumed as a benchmark for the authors.

Table 1. EntreComp competences framework (adapted EntreComp visual model by authors).

\begin{tabular}{cc}
\hline EntreComp Groups of Competences & Competence \\
\hline Ideas and Opportunities & C1: Spotting Opportunities \\
Ideas and Opportunities & C2: Creativity \\
Ideas and Opportunities & C3: Vision \\
Ideas and Opportunities & C4: Valuing Ideas \\
Ideas and Opportunities & C5: Ethical and Sustainable Thinking \\
Ideas and Opportunities & C6: Self-awareness and self-efficacy \\
Resources & C7: Motivation and Perseverance \\
Resources & C8: Mobilizing Resources \\
Resources & C9: Financial and Economic Literacy \\
Resources & C10: Mobilizing Others \\
Resources & C11: Taking the Initiative \\
Into Action & C12: Planning and Management \\
Into Action & C13: Coping with Ambiguity and Risk \\
Into Action & C14: Working with Others \\
Into Action & C15: Learning Through Experience \\
\hline
\end{tabular}

\section{Results}

\subsection{Finland}

The Finnish business scene has undergone a historical shift from a playing field dominated by a few large companies to a dynamic business ecosystem dominated by several small enterprises. Most new jobs are now being created by small and mid-size enterprises, especially in technology- and innovation-based growth enterprises, which had accounted for most of the economy's productivity gains [61]. Most Finnish companies belong to so-called micro-businesses, with the number of employees amounting to 10. In 2014, 2016 and 2017, the percentage of such micro-businesses was a little above $93 \%$ of all businesses in Finland. There was also a general growth tendency in the number of medium and large companies, with the number of employees amounting to between 20 and 49 and over 50, respectively [62].

The Finnish start-up ecosystem contains many accelerators, angel investors, and venture capitalists, and has strong innovation support from the government. The capital city, Helsinki, ranks number 
one in the world in local connectedness among founders, investors and experts. Eighty-two accelerators/incubators offered their services in Finland in 2017.

About 4000 start-up companies begin operating in Finland each year. Of them, around 300-400 are "high growth start-ups". Start-ups accounted for $8.9 \%$ of the total enterprise stock. The highest number of start-ups was in professional, scientific and technical activities, with 5800 start-ups, or $16 \%$ of all start-ups in 2018 [63].

Five Finnish entrepreneurs took part in interview sessions in April of 2019. Due to the varied availability of the respondents, the focus group activity was substituted by interview sessions. Each session lasted one hour. All interviewed entrepreneurs had a high intercultural profile-sharing Finnish and other nations' backgrounds, being actively involved in entrepreneurship development of the Kymenlaakso region. Entrepreneurs mainly pointed to the necessity of learning openly and to identifying personality issues when leading others or learning from others. At the same time, some entrepreneurs mentioned that passion helps to cope with daily routine. Both hard (e.g., ICT skills) and soft skills (i.e., people skills) were reflected by the focus group as necessary, while management competences and leadership skills were identified as the most important skills for a start-up entrepreneur to succeed.

\subsubsection{Finnish Entrepreneurs-Level of Importance of Competences}

The respondents evaluated the importance of the EntreComp competences. The most demanded competences (top three with the highest weighted rank) were (1) motivation and perseverance (20), (2-3-4) creativity (19), (2-3-4) spotting opportunities (19), (2-3-4) learning through experience. The least demanded competences (top three with the lowest weighted rank) were (1-2) financial and economic literacy (12), (1-2) ethical and sustainable thinking (12), and (3) mobilizing others (13). Note that further in the text, in the descriptive part, the figures in brackets contain the cumulative weighted values of the EntreComp competences ranked on a scale from one to four, that is, from least important to highly important.

Even though the entrepreneurs deal with intercultural products and cross-national clients, they all pointed at valuing ideas and ethical and sustainable thinking as less important (or unimportant) compared to motivation and perseverance. Since most entrepreneurs are small-scale entrepreneurs or individual entrepreneurs, mobilizing others as a competence does not apply fully to their business profiles, and this might be considered as an explanation for its low score.

\subsubsection{HEIs and BSIs in Finland-Level of Performance}

Answers from three HEIs and four of the six BSIs were analyzed in order to gain an overview of the competence performance levels in their organizations. Each representative evaluated the competences on a scale from 1 (the least performed) to 4 (highly performed), and could also reply non-applicable where the competence was not performed at all in the institution. The results were weighed based on the number of times it gained evaluation on the scale from one to four.

The least trained competences were: (1) activating the market, (2-3-4) mobilizing others, (2-3-4) financial and economic literacy, (2-3-4) ethical and sustainable thinking. The most trained competences were: (1) working with others, (2) spotting opportunities, (3-4-5-6) creativity, (3-4-5-6) self-awareness and self-efficacy, (3-4-5-6) motivation and perseverance, (3-4-5-6) planning and management, and (3-4-5-6) learning through experience.

When this data was compared to the results of the demanded competences in Finland, three of the least trained competences were the least demanded by entrepreneurs-financial and economic literacy, ethical and sustainable thinking and mobilizing others. Comparing the highest levels of importance and performance of the competences, all four competences pointed out by the entrepreneurs matched this equilibrium with HEIs and BSIs opinions-spotting opportunities, motivation and perseverance, learning through experience and creativity. 
3.1.3. The Importance-Performance Analysis of the EntreComp Competences Evaluation in Finland

In accordance with the importance-performance analysis (IPA) method, the performance and importance values were calculated as the ratio between the cumulative weighted values and the number of respondents in the sample. In accordance with the method, the numbers represent the position of the researched competence on the IPA chart in one of the four quadrants.

In conformity with the method, competences such as self-awareness and self-efficacy as well as coping with uncertainty, ambiguity and risk were displayed in the "Concentrate Here" section. This might be interpreted as an instruction for HEIs and BSIs in Finland to draw attention to the competences training due to the discrepancy in evaluations. Educational and supporting activities aimed to develop abilities for working with others and taking the initiative, which might become lower in intensity as their positioning in the "Possible Overkill" quadrant communicates about the lack of direct benefit from the activities due to the low importance of the competence for the Finnish market. There are no new findings for the research in "Keep Up the Good Work" and "Low Priority" quadrants, as these recommendations are in line with the previously mentioned findings. The IPA chart based on data gathered in Finland in 2019 can be found in Figure 1.

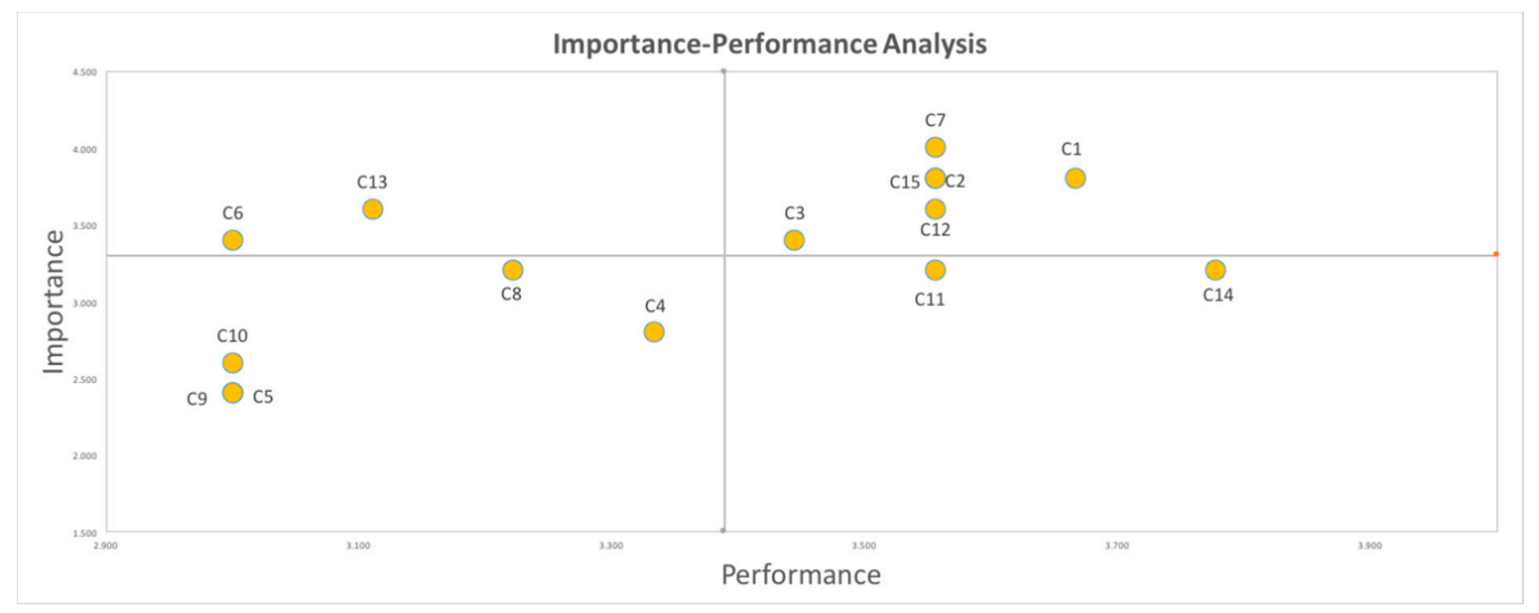

Figure 1. IPA chart based on data gathered in Finland, 2019 (created by authors). where C1—Spotting Opportunities, C2-Creativity, C3-Vision, C4-Valuing Ideas, C5-Ethical and Sustainable Thinking, C6-Self-awareness and Self-efficacy, C7-Motivation and Perseverance, C8-Mobilizing Resources, C9-Financial and Economical literacy, C10-Mobilizing Others, C11-Taking the Initiative, C12-Planning and Management, C13-Coping with Uncertainty, Ambiguity, and Risk, C14_Working with Others, and C15-Learning Through Experience.

\subsection{Latvia}

The Latvian entrepreneurship ecosystem is small, yet vibrant, and consists of highly motivated multilingual (often with at least three languages or more) talented people of various ages and backgrounds. The start-up environment is dynamic and rapidly growing. The main actors of the entrepreneurship ecosystem in Latvia are government, academia and capital and support the start-up ecosystem due to the increasing role of start-ups in the national economy. Support for innovative companies is one of the priorities of the government. It is defined in the national level planning documents such as the Sustainable Development Strategy of Latvia until 2030, the National Development Plan 2014-2020, and the Government Action Plan. Business incubators are great contributors to the growth of the entrepreneurial spirit in the main regions of Latvia. In total, there are over 25 business incubators, of which 15 are government-led, 11 are under the umbrella of universities, and there are four private business incubators, of which three are "Kurzemes Business incubator" in western Latvia and one operates within "Ventspils HighTech Park". The Latvian start-up infrastructure consists of $400+$ registered start-ups, a pool of institutional investors and business angels, a diverse range 
of modern co-working spaces, and dozens of business incubators $[64,65]$ fueled by the government, academia and private individuals.

Six entrepreneurs took part in the focus group activity in February 2019. It lasted for $1.5 \mathrm{~h}$. Three of the respondents commercialized their products on an international scale, the rest operated locally. The fields the entrepreneurs represented were manufacturing, business consulting, IT, and interior design. While the sectors of economy do not make a great impact on the dynamics of the domestic GDP and are not as productive as construction or electricity supply industries [66], development of the right skills set could significantly improve the productivity of an enterprise. One competence was separately distinguished from the EntreComp list, namely, activating the market which is the ability to be able to create demand for the product, to be knowledgeable about the market and to use this knowledge for the benefit of the start-up. It can also include disruptions in the market.

\subsubsection{Latvian Entrepreneurs-Level of Importance of Competences}

In accordance with the data gathered from the Latvian entrepreneurs' sample, the most demanded competences (top three with the highest weighted rank) were: (1) coping with uncertainty, ambiguity and risk, (2-3) motivation and perseverance, and (2-3) planning and management. The least demanded competences (top three with the lowest weighted rank) were: (1) ethical and sustainable thinking, (2) financial and economic literacy, and (3) creativity. The questioned stability of the financial system in the country and its ability to support growth in the economy, as well as other negative internal factors, such as a strained labor market, decline in population, and slower than expected external growth, might be defined as the root causes of the highest ranking for the competence of coping with risks and uncertainty [67]. It is interesting that both Latvian and Finnish start-up entrepreneurs pointed to ethical and sustainable thinking as well as financial and economic literacy competences as the least important.

\subsubsection{HEIs and BSIs in Latvia-Level of Performance}

The researchers conducted interviews and EntreComp competences evaluation with entrepreneurship training institutions. The respondents were three higher education institution representatives whose competences covered the execution of entrepreneurship training curricula within the study program, a course or extracurricular activity, especially regarding the best practice of the institution. To extend the research and understand entrepreneurship training within the entrepreneurship ecosystem, the researchers also conducted five interviews with entrepreneurship supporting organizations, i.e., business incubators, accelerators and one co-working space; eleven institutions in total were interviewed. The least trained competences were: (1) self-awareness and self-efficacy, (2) coping with uncertainty, ambiguity and risk, and (3) financial and economical literacy. The most trained competences were: (1-2) learning through experience, (1-2) valuing ideas, and (3) spotting opportunities.

It is worth mentioning that Latvian entrepreneurs' opinions were not aligned with educational and supporting activities of the domestic HEIs and BSIs. For example, the competence of coping with uncertainty, ambiguity and risk, which was ranked as highly important by businesspeople, was ranked as the least important by HEIs and BSIs, while the other competences considered by the start-ups focus group as important (motivation and perseverance as well as planning and management), were not elected by educational institutions or incubators as highly important for training. However, it is also worth noting that Latvian entrepreneurship training activities are aligned with Finnish programs, because competences such as spotting opportunities and learning through experience were considered to be the most trained in both countries.

\subsubsection{The Importance-Performance Analysis of the EntreComp Competences Evaluation in Latvia}

The IPA analysis results confirm the findings observed in the previous steps of the research, motivation and perseverance as well as coping with uncertainty, ambiguity and risk competences, previously identified as highly important for business endeavors in Latvia, were positioned in the 
"Concentrate Here" quadrant. Additionally, the quadrant contained activating market (or marketing) competence, which was identified by Latvian start-up entrepreneurs during a brainstorming session and was deemed to be important for starting a business.

Allocation of Spotting opportunities, creativity, vision, and valuing ideas competences in the "Possible Overkill" quadrant verifies the above statement about the disagreement between Latvian HEIs and BSI educational programs and domestic market needs-these competences were not evaluated by entrepreneurs as highly important, however, they were considered to be the most trained in the institutions. As for the competences exhibited in other quadrants, there was no disagreement with previous findings, see the IPA graph created on the data collected in Latvia in 2019 in Figure 2. It is worth mentioning that the collected data was not sufficient for an interpretation of the mobilizing resources competence positioning on the IPA chart, as it is at the point where the X-axis crosses the Y-axis. Hence, additional data or another method needs to be applied for further analysis. While creativity competence is positioned on the vertical axis, the authors believe that it might be interpreted as positioning in the "Possible Overkill" section due to previous observations.

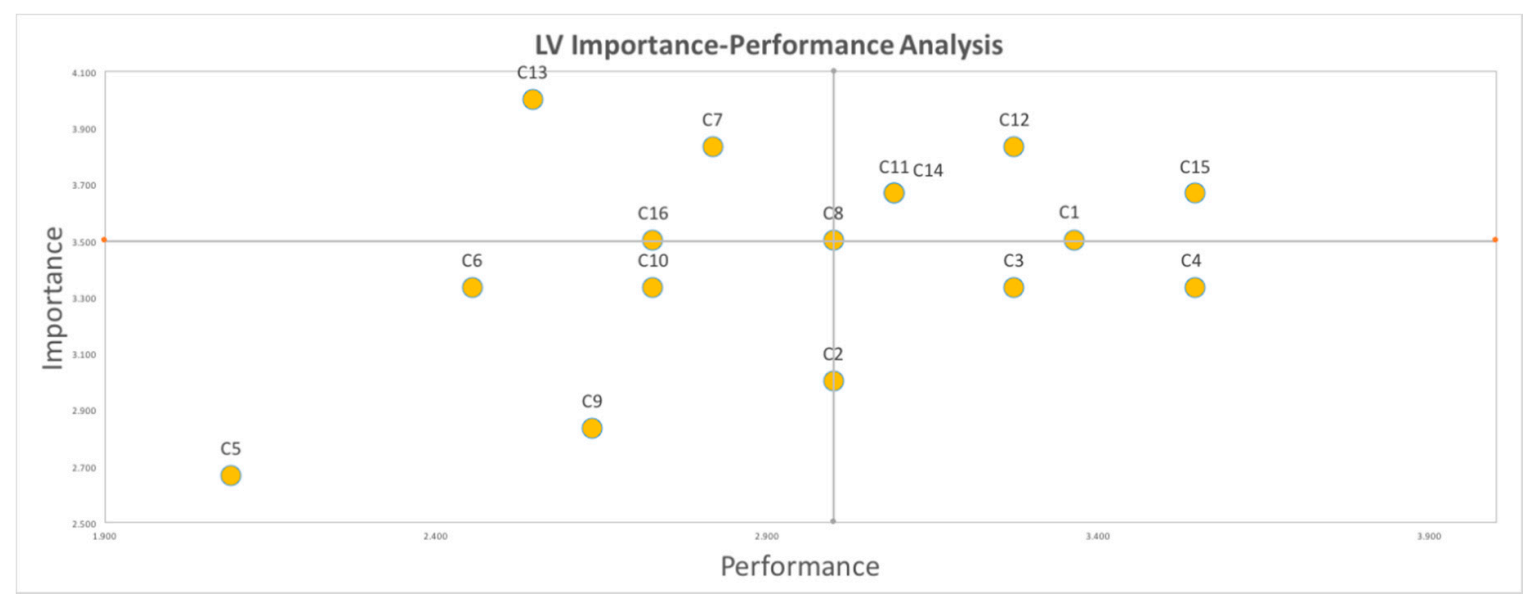

Figure 2. IPA chart based on data gathered in Latvia, 2019 (created by authors). where C1-Spotting Opportunities, C2-Creativity, C3-Vision, C4-Valuing Ideas, C5-Ethical and Sustainable Thinking, C6-Self-awareness and Self-efficacy, C7-Motivation and Perseverance, C8-Mobilizing Resources, C9-Financial and Economical literacy, C10-Mobilizing Others, C11-Taking the Initiative, C12-Planning and Management, C13 - Coping with Uncertainty, Ambiguity, and Risk, C14-Working with Others, C15-Learning Through Experience, and C16-Activating Market.

\subsection{The Netherlands}

Most Dutch companies are micro-businesses with the number of employees amounting to 10. The number of those companies has increased from $93 \%$ in 2014 to $96 \%$ in 2017 . Ranked as number three in the EU on the 2019 Global Innovation Index [68], The Netherlands is home to more than 10 leading innovation hubs, where start-ups benefit from world-class incubators and R\&D facilities. The environment thrives on effective initiatives carried out by the private and the public sectors. There is a strong network of business incubators and accelerators in The Netherlands. The number of incubators and accelerators has grown rapidly, from about 64 in 2014 to more than 100 in 2019. To provide the Dutch incubators and accelerators with a common platform on behalf of professionalization and positioning on a national, European, and international level, the Dutch Incubation Association (DIA) was established in 2004. There are business supporting organizations that do not consider themselves to be an incubator or accelerator, but rather a facilitator of the start-up or entrepreneurial ecosystem by providing common working spaces and facilities, and thereby bringing entrepreneurs together. In 2019, there were over 4000 start-ups in The Netherlands. Nearly 700 of these start-ups were active in enterprise software. 117 companies were active in the travel industry. 
Individual interviews were organized with four entrepreneurs in April 2019. Due to the varied availability of the respondents, the focus group activity was substituted by interview sessions and each session lasted one hour. The fields represented by the entrepreneurs were consulting, food production, medical skincare, production of disinfecting solutions.

\subsubsection{Dutch Entrepreneurs_Level of Importance of Competences}

The most demanded competences (top three with the highest weighted rank): (1) motivation and perseverance, (2-3) spotting opportunities, and (2-3) vision. Motivation and perseverance were complemented by passion and ambition, which were additionally listed and highly valued by the respondents. Spotting opportunities was related to the ability to continually learn and acquire information, to understand when the time could be right for a business idea, and the ability to solve a problem in the form of entrepreneurship. Vision was important in terms of long-term strategy, decision-making and maintaining a focus.

The least demanded competences (top three with the lowest weighted rank): (1) Financial and economic literacy, (2) planning and management, and (3) ethical and sustainable thinking. Financial and economic literacy was considered to be less relevant to the main business activities of the entrepreneur, thus having it outsourced from professionals in the specific field. Planning and management were considered as broad terms and the result of other prevailing competences such as vision, mobilizing resources and working with others. Ethical and sustainable thinking is a social norm in The Netherlands, as opposed to other countries in the European Union. Business success relies on the ability to work within strict and ethical guidelines. Thus, it is not seen as an entrepreneurial competence that needs to be trained separately.

Interestingly, entrepreneurs in all the researched countries unanimously evaluated ethical and sustainable thinking as well financial and economic literacy as the least important for starting a business, while motivation and perseverance were commonly ranked as highly important, despite the obvious differences in economic and historical background of the markets. It probably refers to a mind-set standardization caused by big changes on a global level and leading to technological and cultural homogeneity [69]. It is worth mentioning that, although there are no important differences between social and conventional entrepreneurs, the first ones are motivated by strong ethics [70], hence, as the focus groups representatives belong to the congenital entrepreneurs, their perception about competence differs.

\subsubsection{HEIs and BSIs in The Netherlands-Level of Performance}

Nearly all Dutch tertiary education institutions have developed specific entrepreneurial study programs and modules, with a view to developing entrepreneurial competence and creating new businesses (thus bridging the traditional perceived gap between theory and practice). Despite these overarching goals, both national and international objectives and entrepreneurial training initiatives lie predominantly within the purview of local municipalities. Thus, there is no central organization within The Netherlands that aggregates information pertaining to the number, type, and scope of incubators and start-ups. For example, The Dutch Incubation Association, an informal community practice, lists 54 incubators on their website (omitting several established incubation programs associated with Dutch universities). Furthermore, this decentralized approach means that different institutions develop different entrepreneurial training methods and areas of expertise, including: (medical) technology, maritime, energy, water management, etc. In the context of the research, three institutions were identified and interviewed.

The most performed or trained competences (top three with the highest weighted rank) were (1) taking the initiative, (2-3) working with others and (2-3) motivation and perseverance. The least performed or trained competences (top three with the lowest weighted rank) were (1) ethical and sustainable thinking (2) financial and economic literacy and (3) planning and management. 
Obviously, due to the large funding that The Netherlands has placed on fostering entrepreneurship at all levels in society to strengthen their competitiveness internationally and stimulate innovation, both entrepreneurs and HEIs and BSIs unanimously identified ethical and sustainable thinking, financial and economic literacy as well as planning and management competences as the least important for launching a business and these competences are the least trained competences in the educational programs. At the same time, motivation was considered as highly important by entrepreneurs and as one of the most trained competences in educational institutions. Together with colleagues from Finland, the Dutch HEIs and BSIs representatives ranked the competence of working with others as one of the most performed.

\subsubsection{The Importance-Performance Analysis of the EntreComp Competences Evaluation in} The Netherlands

In accordance with the IPA chart created on the data gathered by the researchers in The Netherlands (see Figure 3), HEIs and BSIs in the country could draw their attention to the role of competences such as Creativity, vision, self-awareness and self-efficacy as well as mobilizing resources, in the educational and supporting programs. Location of the competences in the "Concentrate Here" quadrant represents high importance of the skills for entrepreneurs but low performance in the competence training by institutions, hence the area might be additionally developed.

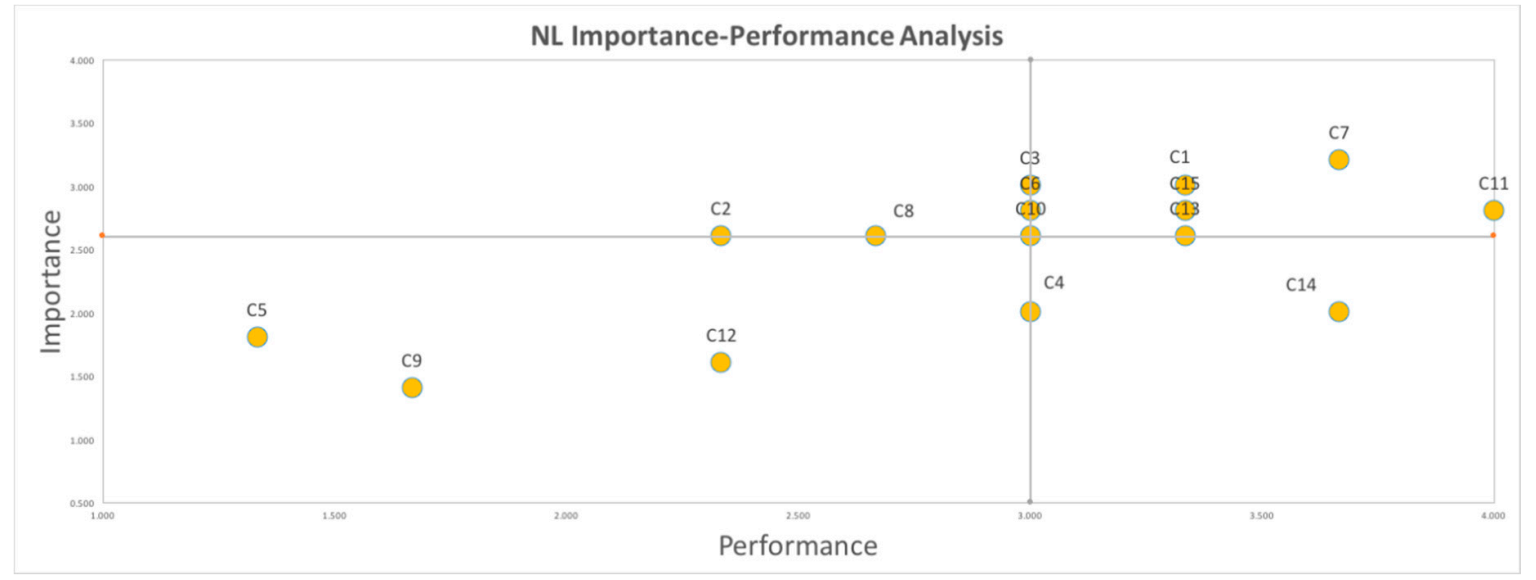

Figure 3. IPA chart based on data gathered in The Netherlands, 2019 (created by authors). where C1-Spotting Opportunities, C2-Creativity, C3-Vision, C4-Valuing Ideas, C5-Ethical and Sustainable Thinking, C6-Self-awareness and Self-efficacy, C7-Motivation and Perseverance, C8-Mobilizing Resources, C9-Financial and Economical literacy, C10-Mobilizing Others, C11-Taking the Initiative, C12-Planning and Management, C13-Coping with Uncertainty, Ambiguity, and Risk, C14-Working with Others, and C15-Learning Through Experience.

At the same time efforts for training and supporting such competences as valuing ideas, coping with uncertainty, ambiguity and risk, as well as working with others might be smaller. There are no major findings regarding the location of the competences in the "Low Priority" and "Keep Up the Good Work" quadrants, as the findings were coherent with the previously mentioned observations. Probably due to the relevant small respondents' sample in The Netherlands, the method does not allow the researchers to comment on the positioning of mobilizing others on the chart.

\section{Discussion}

\subsection{Competences for Stregthening Entrepreneurial Capablity in the Researched Countries}

In summary, the authors were surprised that, despite the divergence of the researched countries in terms of size, population, culture, GDP, and political history, the major findings of the research 
represent similarities in stakeholders' beliefs about competences required for launching a start-up. Interestingly, entrepreneurs in all researched countries unanimously evaluated ethical and sustainable thinking as well as financial and economic literacy as the least important for starting a business, although the need and interest in these disciplines is growing [11,71,72]. The moderate interest towards business ethics was explained by researchers who distinguished responsible entrepreneurs from purely for-profit entrepreneurs [73], hence the results might be assumed as expected, considering that the interviewed sample includes entrepreneurs focused on launching their businesses. Motivation and perseverance were also commonly ranked as highly important despite the obvious differences in the economic and historical background of the markets. The reflection is aligned with the acknowledgement of entrepreneurial passions outcomes and its importance in driving many entrepreneurial endeavors [74-78].

Analyzing the data gathered in Finland, the authors detected that competences such as self-awareness and self-efficacy as well as coping with uncertainty, ambiguity and risk are displayed in the "Concentrate Here" section, so, this might be interpreted as an instruction for HEIs and BSIs to direct their attention to competences training due to the requested demand for the abilities. The observation about the importance of self-knowledge is one of the "entrepreneur skills" that is relevant to uncovering the work done by earlier academic researchers [79-82]. The entrepreneurs' statement of the significance of risk tolerance for launching a start-up is in accordance with previous findings of other researchers stressing that HEIs and business supporting organizations need to cultivate more resilient attitudes toward risks $[11,83]$. At the same time, the institutions might spend less effort in developing abilities on working with others and taking initiative. Valuing ideas and mobilizing others competences got low scores by Finnish entrepreneurs.

Latvian start-up entrepreneurs defined an additional competence that was not included in the EntreComp Framework, namely, activating market, which they assessed as crucial for a business start on the domestic market. It should be noted that Latvian entrepreneurs' opinions are not aligned with educational and supporting activities of the domestic HEIs and BSIs. For example, competence for coping with uncertainty, ambiguity and risk, which were ranked as highly important by businesspeople, was ranked as the least performed by HEIs and BSIs, while the other competences considered by start-ups focus group as important (motivation and perseverance or planning and management) were not elected by educational institutions or incubators as highly important for training. The findings about the gaps between graduates' competences and industry demand, as well as business incubators as a remedy to close the gap, correspond to other researchers' detections $[72,84]$. These recommendations contribute to previous findings by researchers that have investigated successful knowledge transfer and its performance measurement [85]. It is worth noting that Latvian entrepreneurship training activities are aligned with Finnish programs, as competences such as spotting opportunities and learning through experience were considered as the most trained in both countries.

In The Netherlands, both entrepreneurs and HEIs and BSIs unanimously identified ethical and sustainable thinking, financial and economic literacy as well as planning and management competences as the least important for launching a business and these competences as the least trained competences in educational programs. At the same time motivation, considered as highly important by entrepreneurs, is one of the most trained in the educational institutions. Together with colleagues from Finland, the Dutch HEIs and BSIs representatives ranked the competence of working with others as one of the most performed. The Dutch HEIs and BSIs could draw their attention to the role of the competences such as creativity, vision, self-awareness and self-efficacy as well as mobilizing resources, in the educational and supporting programs.

\subsection{The Relation between Entrepreneurial Capability and Open Innovation}

In answering the research question about entrepreneurial competences demanded by most of the domestic markets in Finland, Latvia, and The Netherlands, and whether the needs are aligned with the entrepreneurship education and business supporting policies in the countries in this study, 
the authors make a contribution towards previous studies on the entrepreneurship culture for open innovation dynamics. The sought findings by researching start-ups, HEIs, and BSIs increase the conceptual understanding of a novice entrepreneur, who is considered by other researchers as a driving force that moves towards a new combination of technology and the market in open innovation dynamics through the creation of new products, services, and organizations [86]. These authors proposed a concept model for "culture for open innovation dynamics" and believe that this culture matches that of open innovation-based start-ups and SMEs. Upon carrying out the research with the respondent samples that are in the "Go-Go" stage of the Adizes Corporate Lifecycle model, the paper provides new insights about novice entrepreneurs. While culture as a set of traits or characteristics, in general, is rather static [86], culture can be changed in the long run. An increasing acceptance of the open innovation concept as a basis for innovation creation and business development is strong evidence of that. Open innovation culture serves as a driving force for both established and start-up business development [87]. During the last decade, HEIs have been playing an increasing role in entrepreneurship culture development. Competences evaluated according to the EntreComp model can be treated as constituents of the entrepreneurship culture. To develop the most effective combination of entrepreneurial competences, it is important to identify and develop the critical ones and develop an appropriate teaching methodology to be used by HEIs, which is the major goal of the previously mentioned project.

Modern researchers believe that the contemporary economy can be modeled as entrepreneurial cyclical dynamics of open innovation with three sub-economies: market open innovation by SMEs and start-ups, closed open innovation by big business, and social open innovation. The researchers assume that leaders in this economy are start-ups [88]. Therefore, it is highly important to evaluate whether HEIs and BSIs train students according to the requirements of the contemporary market and prepare them for a prompt entrance to the open innovation economy.

\section{Conclusions}

\subsection{Implication}

The project researcher team is interested in developing the entrepreneurship training methodology for transdisciplinary students to enhance entrepreneurial competence dissemination and development across education programs and beyond. Upon studying the information about the training methods of entrepreneurial competences and their development, in comparison to the actual market demand, the authors concluded that there are many variances as well as similarities in entrepreneurial competence distribution among the IPA quadrants of High Importance/Low Performance ("Concentrate Here"), High Importance/High Performance ("Keep Up the Good Work"), Low Importance/Low Performance ("Low Priority"), and Low Importance/High Performance ("Possible Overkill”).

\subsection{Limits and Future Research Topic}

We believe that the topic of entrepreneurial competences is quite challenging when defining a common ground for their meaning; other researchers have also indicated this conclusion earlier. A recent suggestion was to add an additional dimension to the competence evaluation-execution. However, due to the limitations of the research, (1) the sample size of five respondents for a focus group, (2) three countries' entrepreneurship ecosystems from the perspective of higher education institutions-based investigation, (3) business start-up focused respondents that do not concentrate on high growth, (4) other project limitations, the multi-dimensional investigation was not applied and is considered to be the subject for further research in the field, and (5) the research conducted in the scope of a dedicated ERASMUS+ project and is considered as a pilot phase of investigation on the topic, hence the findings and observations are assumed as preliminary and could not be extrapolated to all countries in Europe. 
Acknowledging that the findings and conclusions are based on the experts' opinions, as well as the other limitations of the study, further research is needed to examine whether increases in the respondents' sample size will conform to the observations stated above. To validate the sought findings, future research should include quantitative methods, additional in-depth research in Finland, Latvia, The Netherlands, as well as application of the research practice in other countries. The current findings are applied for the pilot research as the first phase of preliminary assessment of the situation in the researched countries, hence, the IPA methodology was used to unite the opinions of two different groups examined by the authors, while semi-structured expert interviews were considered as a valuable source for entrepreneurship training methodology development.

Author Contributions: Conceptualization, I.L. and M.O.; methodology, I.L.; software, T.N.; validation, I.L. and T.N.; formal analysis, T.N.; investigation, M.N., M.P., M.S., M.M.I., M.O., I.L., T.N.; resources, M.N., M.P., M.S., M.M.I., T.N.; data curation, M.M.I., T.N.,; writing-original, T.N.,; writing-review and editing, M.M.I., M.O., I.L., T.N.; visualization, T.N.; supervision, I.L.; project administration, M.M.I., M.O.; funding acquisition, M.O. All authors have read and agreed to the published version of the manuscript.

Funding: This research was funded by the ERASMUS+ programme of the European Union within Strategic partnerships for higher education "European Entrepreneurship Training Community: Augmenting academic entrepreneurial training methodology, international students' entrepreneurship community, and fundamental entrepreneurial university network" (No.2018-1-LV01-KA203-046974).

Conflicts of Interest: The authors declare no conflict of interest.

\section{References}

1. Nikitina, T.; Lapina, I. The Concept of Manager: Critical Analysis and Competencies Required. In Proceedings of the 10th International Scientific Conference "Business and Management 2018", Lithuania, Vilnius, 3-4 May 2018; Selected Papers. pp. 236-244, ISBN 978-609-476-119-5, e-ISBN 978-609-476-118-8. [CrossRef]

2. Nikitina, T.; Lapina, I. Today's Business and Entrepreneurship Development: Knowledge Dynamics and Competences of Managers and Entrepreneurs. In Knowledge Ecosystems and Growth, Proceedings of the 14th International Forum on Knowledge Asset Dynamics (IFKAD 2019), Matera, Italy, 5-7 June 2019; University of Basilicata, Institute of Knowledge Asset Management (IKAM): Matera, Italy, 2019; pp. 2336-2348, ISBN 978-88-96687-12-3.

3. OECD. Developing Entrepreneurship Competencies. In Proceedings of the OECD Ministerial Conference on Small and Medium-sized Enterprises, Mexico City, Mexico, 22-23 February 2018.

4. Cohen, L.; Musson, G. Entrepreneurial Identities: Reflections from Two Case Studies. Organizations 2000, 7, 31-48. [CrossRef]

5. Man, T.W.Y. Entrepreneurial Competencies and the Performance of Small and Medium Enterprises in the Hong Kong Services Sector. Ph.D. Dissertation, Polytechnic University, Hong Kong, China, 2001.

6. Nikitina, T.; Lapina, I. Creating and Managing Knowledge towards Managerial Competence Development in Contemporary Business Environment. Knowl. Manag. Res. Pract. 2019, 17, 96-107. [CrossRef]

7. Huck, J.F.; McEwen, T. Competencies Needed for Small Business Success: Perceptions of Jamaican Entrepreneurs. J. Small Bus. Manag. 1991, 29, 90-93.

8. Smith, B.; Morse, E. Entrepreneurial Competencies: Literature Review and Best Practices; Small Business Policy Branch Industry: Ottawa, ON, Canada, 2005.

9. Gaile-Sarkane, E. Semi Management Theory and Business Sophistication. In Proceedings of the 16th World Multi-Conference on Systemics, Cybernetics and Informatics (WMSCI 2012), Orlando, FL, USA, 17-20 July 2012; pp. 25-30.

10. Roša, A.; Lāce, N. The Open Innovation Model of Coaching Interaction in Organizations for Sustainable Performance within the Life Cycle. Sustainability 2018, 10, 3516. [CrossRef]

11. Mitchelmore, S.; Rowley, J. Entrepreneurial competencies: A literature review and development agenda. Int. J. Entrep. Behav. Res. 2010, 16, 92-111. [CrossRef]

12. Lans, T.; Blok, V.; Wesselink, R. Learning apart and together: Towards an integrated competence framework for sustainable entrepreneurship in higher education. J. Clean. Prod. 2014, 62, 37-47. [CrossRef] 
13. Dentoni, D.; Blok, V.; Lans, T.; Wesselink, R. Developing human capital for agrifood firms' multi-stakeholder interactions. Int. Food Agribus. Manag. Rev. 2012, 15, 61-68.

14. Peterka, S.O.; Koprivnjak, T.; Mezulić, P. Challenges of Evaluation of the Influence of Entrepreneurship Education. Econ. Rev.-J. Econ. Bus. 2015, 13, 74-86.

15. Eurostat. Annual Enterprise Statistics by Size Class and NACE Rev. 2 Activity (B-N_X_K). Available online: http://appsso.eurostat.ec.europa.eu/ (accessed on 15 April 2020).

16. Saginova, O.V.; Grishina, O.A.; Shtyhno, D.A. Проектноеобучение студентов на основе заказов малых и средних предпринимательских структур. РоссийскоеПредпринимательство 2017, 18, 417-425.

17. Hoffmann, R. Ecovis Beijing. Small and Medium Enterprises (SMEs) in China 4 July 2017. Available online: https://ecovis-beijing.com/smes-china/ (accessed on 15 April 2020).

18. Korsakiene, R.; Diskiene, D. Do Competencies of Entrepreneurs and Managers Influence Internationalization Processes? Investigation of Lithuanian SMEs. In Proceedings of the European Conference on Innovation \& Entrepreneurship, Genoa GE, Italy, 17-18 September 2015; pp. 384-391.

19. Annual Report on European SMEs 2018/2019. 2019. Available online: https://op.europa.eu/en/publicationdetail/-/publication/b6a34664-335d-11ea-ba6e-01aa75ed71a1/language-en/format-PDF/source-search (accessed on 13 July 2020).

20. Gordon, J.; Bursuc, V. Law and Entrepreneurship Education: A Proposed Model for Curriculum Development. J. Leg. Stud. Educ. 2018, 35, 123-141. [CrossRef]

21. Fayolle, A.; Gailly, B. The Impact of Entrepreneurship Education on Entrepreneurial Attitudes and Intention: Hysteresis and Persistence. J. Small Bus. Manag. 2013, 4, 29-42. [CrossRef]

22. Katongole, C.; Munene, J.C.; Ngoma, M. Entrepreneur's Intrapersonal Resources and Enterprise Success among Micro and Small Scale Women Entrepreneurs. J. Enterp. Cult. 2015, 23, 405-447. [CrossRef]

23. Arranz, N.; Ubierna, F.; Arroyabe, M.F.; Perez, C.; Arroyabe, F.D. The effect of curricular and extracurricular activities on university students' entrepreneurial intention and competences. Stud. High. Educ. 2017, 42, 1979-2008. [CrossRef]

24. Sun, H.; Lo, C.T.; Liang, B.; Wong, Y.L. The Impact of Entrepreneurial Education on Entrepreneurial Intention of Engineering Students in Hong Kong. Manag. Decis. 2017, 55, 1371-1393. [CrossRef]

25. Aaboen, L.; Landström, H.; Sørheim, R. (Eds.) How to Become an Entrepreneur in a Week, the Value of 7-Day Entrepreneurship Courses; Edward Elgar Publishing: Cheltenham, UK, 2020; p. 232, ISBN 978-1-78897-927-6.

26. Hrehová, D.; Gluchman, M. Education of technical university students with an emphasis on entrepreneurial activities. In Proceedings of the Multidisciplinary Academic Conference, Prague, Czech Republic, 7-8 August 2015; pp. 1-6.

27. Hrehová, D.; Ilečko, T. Development and support of entrepreneurial competencies for career growth. In Proceedings of the Multidisciplinary Academic Conference, Prague, Czech Republic, 27-28 May 2016; pp. 227-232.

28. Husremović, D.; Džumhur, Ž.; Đapo, N. Integracija Ključnih Kompetencija U Ishode Učenja. In Proceedings of the Biannual Congress of Psychologists of Bosnia \& Herzegovina, Sarajevo, Bosnia and Herzegovina, 2-4 March 2017; pp. 299-323.

29. Isaila, N. The Role of Educational Technologies to Develop Entrepreneurial Competences. Knowl. Horiz. Econ. 2015, 7, 105-107.

30. Chalupský, V.; Schüller, D.; Chlebovský, V. Development of Entrepreneurial Skills and Competences through Business Simulations. In Proceedings of the International Multidisciplinary Scientific Conference on Social Sciences \& Arts SGEM, Albena, Bulgaria, 24-30 August 2016; pp. 183-188.

31. Petrylaite, E. Application of SME Marketing Model within Higher Education Entrepreneurial Teams. In Proceedings of the European Conference on Innovation \& Entrepreneurship, Aveiro, Portugal, 20-21 September 2018; pp. 1060-1063.

32. Ferreras-Garcia, R.; Hernández-Lara, A.B.; Serradell-López, E. Entrepreneurial competences in a higher education business plan course. Educ. Train. 2019, 61, 850-869. [CrossRef]

33. Abereijo, I.O. Developing Entrepreneurial Competences in University Lecturers: Obafemi Awolowo University Experience. KCA J. Bus. Manag. 2015, 6, 30-42.

34. Oganisjana, K. Promotion of university students' collaborative skills in open innovation environment. J. Open Innov. Technol. Mark. Complex. 2015, 1, 18. [CrossRef] 
35. Beyhan, B.; Findik, D. Student and graduate entrepreneurship: Ambidextrous universities create more nascent entrepreneurs. J. Technol. Transf. 2018, 43, 1346-1374. [CrossRef]

36. Molina-Osorio, V.; Molina-Osorio, A. Universities Fostering Entrepreneurship Ecosystems: From Teaching Entrepreneurship to Being Entrepreneurial. In Proceedings of the European Conference on Innovation \& Entrepreneurship, Aveiro, Portugal, 20-21 September 2018; pp. 490-506.

37. Manning, L. Enabling entrepreneurial behaviour in a land-based university. Educ. Train. 2018, 60, 735-748. [CrossRef]

38. Jakubiak, M.; Chrapowicki, P. Wpływ kompetencji przedsiębiorczych naukowców na współprace nauki i biznesu. Educ. Econ. Manag./Edukacja Ekonomistow i Menedzerow 2018, 48, 95-111. [CrossRef]

39. Schiuma, G.; Carlucci, D. Managing Strategic Partnerships with Universities in Innovation Ecosystems: A Research Agenda. J. Open Innov. Technol. Mark. Complex. 2018, 4, 25. [CrossRef]

40. Barnett, B.; Wieder, A.; Byrd, A. Teacherpreneurs: Innovative Teachers Who Lead But Don't Leave; Jossey-Bass: San Francisco, CA, USA, 2013; ISBN 10 111845619X.

41. Goi, H.C.; Kokuryo, J. Design of a University-Based Venture Gestation Program (UVGP). J. Enterp. Cult. 2016, 24, 1-35. [CrossRef]

42. Mankevich, V.; Holmström, J. Gateways to Digital Entrepreneurship: Investigating the Organizing Logics for Digital Startups. In Academy of Management Proceedings; Academy of Management: Anaheim, CA, USA, 2017; Volume 2016.

43. Gavurova, B.; Belas, J.; Kotaskova, A.; Cepel, M. Management of Education Concepts in the Fiedl of Entrepreneurship of University Students in the Czech Republic. Pol. J. Manag. Stud. 2018, 17, 52-62. [CrossRef]

44. Zellweger, T.; Sieger, P. Coming Home or Breaking Free? Career Choice Intentions of the Next Generation in Family Businesses; Ernst \& Young: London, UK, 2012.

45. Volkov, D.A.; Ilyin, A.B. The development of family business as a synergy of entrepreneurial competencies. Российское предпринимательство 2018, 18, 439-450.

46. Wang, S.; Wang, Y.; Archer, N. The co-evolution of IT competence, organisational agility and entrepreneurial action: A case study of entrepreneurial e-tailers. Int. J. Netw. Virtual Organ. 2018, 18, 1-29. [CrossRef]

47. Sheng, M.L. Foreign tacit knowledge and a capabilities perspective on MNEs' product innovativeness: Examining source-recipient knowledge absorption platforms. Int. J. Infor. Manag. 2019, 44, 154-163. [CrossRef]

48. Abatecola, G.; Uli, V. Entrepreneurial competences, liability of newness and infant survival: Evidence from the service industry. J. Manag. Dev. 2016, 35, 1082-1097. [CrossRef]

49. Brodack, F.; Sinell, A. Boosting entrepreneurial potential: The effects of interdisciplinary team composition on entrepreneurial capital. In Proceedings of the ISPIM Conferences, Stockholm, Sweden, 17-20 June 2018; pp. 1-19.

50. Erikson, T. Entrepreneurial capital: The emerging venture's most important asset and competitive advantage. J. Bus. Ventur. 2002, 17, 275-290. [CrossRef]

51. Ng, H.S.; Kee, D.M.H.; Ramayah, T. Examining the mediating role of innovativeness in the link between core competencies and SME performance. J. Small Bus. Enterp. Dev. 2019, 27, 103-129. [CrossRef]

52. Rosha, A.; Lace, N. The scope of coaching in the context of-organizational change. J. Open Innov. Technol. Mark. Complex. 2016, 2, 2. [CrossRef]

53. Breschi, S.J.; Lassébie, C.; Menon, C. A portrait of innovative start-ups across countries. In OECD Science, Technology and Industry Working Papers; OECD: Paris, France, 2018.

54. Skala, A. Digital Startups in Transition Economies Challenges for Management, Entrepreneurship and Education; Palgrave Pivot: Cham, Switzerland, 2019. [CrossRef]

55. Adizes, I. Managing Corporate Lifecycles; Adizes Institute Publishing: Carpinteria, CA, USA, 2004.

56. Bacigalupo, M.; Kampylis, P.; Punie, Y.; Van den Brande, G. EntreComp: The Entrepreneurship Competence Framework; EUR 27939 EU June 2016; Publication Office of the European Union: Luxembourg, 2016. 
57. Mccallum, E.; Weicht, R.; Mcmullan, L.; Price, A.; Bacigalupo, M.; O'Keeffe, W. EntreComp into Action. Get Inspired. Make It Happen. A User Guide to the European Entrepreneurship Competence Framework; Publications Office of the European Union: Luxembourg, 2018; Available online: https://ec.europa.eu/jrc/en/publication/eur-scientific-and-technical-research-reports/EntreCompaction-get-inspired-make-it-happen-user-guide-european-entrepreneurship-competence (accessed on 30 April 2020).

58. Carson, D.; Glimore, A.; Perry, C.; Gronhauigh, K. Qualitative Marketing Research; Sage: London, UK, 2001; p. 239, ISBN 0-7619-6365-0.

59. Martilla, J.A.; James, J.C. Importance-performance analysis. J. Market. 1977, 41, 77-79. [CrossRef]

60. Līce, A.; Volkova, T.; Zvaigzne, A. Meeting employers' expectations on employability competencies of higher education graduates. In Proceedings of the 12th European Quality Assurance Forum. Responsible QA-Committing to Impact, Riga, Latvia, 23-25 November 2017.

61. European Commission. Available online: https:/ec.europa.eu/home-affairs/sites/homeaffairs/files/09a finland_start_ups_final_en.pdf (accessed on 30 April 2020).

62. Yrittäjyys Suomessa. Available online: https://www.yrittajat.fi/suomen-yrittajat/yrittajyys-suomessa-316363 (accessed on 30 April 2020).

63. Tilastokeskus. Available online: http://www.stat.fi/til/aly/2018/aly_2018_2019-10-31_tie_001_fi.html (accessed on 30 April 2020).

64. Magnetic Latvia. Available online: http://inkubatori.magneticlatvia.lv/en/ (accessed on 30 April 2020).

65. Rostoka, Z.; Locovs, J.; Gaile-Sarkane, E. Open Innovation of New Emerging Small Economies Based on University-Construction Industry Cooperation. J. Open Innov. Technol. Mark. Complex. 2019, 5, 10. [CrossRef]

66. Danileviciene, I.; Lace, N. The features of economic growth in the case of Latvia and Lithuania. J. Open Innov. Technol. Mark. Complex. 2017, 3, 21. [CrossRef]

67. Emerging Europe. Available online: https://emerging-europe.com/news/imf-latvian-economy-increasinglyresilient/ (accessed on 15 April 2020).

68. Investinholland. Available online: https://investinholland.com/news/the-netherlands-global-innovationleader/ (accessed on 30 April 2020).

69. Šimelytė, A.; Korsakienè, R.; Ščeulovs, D. Americanization in Lithuania as a driving force for globalization. J. Open Innov. Technol. Mark. Complex. 2017, 3, 16. [CrossRef]

70. Svirina, A.; Zabbarova, A.; Oganisjana, K. Implementing open innovation concept in social business. J. Open Innov. Technol. Mark. Complex. 2016, 2, 20. [CrossRef]

71. Medne, A.; Lapina, I. Sustainability and Continuous Improvement of Organization: Review of Process-Oriented Performance Indicators. J. Open Innov. Technol. Mark. Complex. 2019, 5, 49. [CrossRef]

72. Sudana, I.M.; Apriyani, D.; Supraptono, E.; Kamis, A. Business incubator training management model to increase graduate competency. Benchmark. Int. J. 2019, 26, 773-787. [CrossRef]

73. Vallaster, C.; Kraus, S.; Kailer, N.; Baldwin, B. Responsible entrepreneurship: Outlining the contingencies. Int. J. Entrep. Behav. Res. 2018. [CrossRef]

74. Baum, J.R.; Locke, E.A. The relationship of entrepreneurial traits, skill, and motivation to subsequent venture growth. J. Appl. Psychol. 2004, 89, 587-598. [CrossRef]

75. Drnovsek, M.; Cardon, M.S.; Patel, P.C. Direct and indirect effects of passion on growing technology ventures. Strateg. Entrep. J. 2016, 10, 194-213. [CrossRef]

76. Ho, V.T.; Pollack, J.M. Passion isn't always a good thing: Examining entrepreneurs' network centrality and financial performance with a dualistic model of passion. J. Manag. Stud. 2014, 51, 433-459. [CrossRef]

77. Vallerand, R.J.; Mageau, G.A.; Ratelle, C.; Leonard, M.; Blanchard, C.; Koestner, R.; Gagne, M. Les pasions de l'ame: On obsessive and harmonious passion. J. Personal. Soc. Psychol. 2003, 85, 756-767. [CrossRef] [PubMed]

78. Stenholm, P.; Nielsen, M.S. Understanding the emergence of entrepreneurial passion. The influence of perceived emotional support and competences. Int. J. Entrep. Behav. Res. 2019, 25, 1368-1388. [CrossRef]

79. Fiet, J.O. The pedagogical side of entrepreneurship theory. J. Bus. Ventur. 2001, 16, 101-117. [CrossRef]

80. Martinez, M.A.; Aldrich, H.E. Networking strategies for entrepreneurs: Balancing cohesion and diversity. Int. J. Entrep. Behav. Res. 2011, 17, 7-38. [CrossRef]

81. Urban, B. (Ed.) Creating value and innovation through social entrepreneurship. In Frontiers in Entrepreneurship. Perspectives in Entrepreneurship; Springer: Berlin/Heidelberg, Germany, 2010. 
82. Ferrandiz, J.; Fidel, P.; Conchado, A. Promoting entrepreneurial intention through higher education in entrepreneurship and the participation of students in and entrepreneurship ecosystem. Int. J. Innov. Sci. 2018. [CrossRef]

83. Raposo, M.; Paço, A.D. Entrepreneurship education: Relationship between education and entrepreneurial activity. Psicothema 2001, 23, 453-457.

84. Wibowo, N. Upaya memperkecil kesenjangan kompetensi lulusan sekolah menengah kejuruan dengan tuntutan dunia industry. Jurnal Pendidikan Teknologi dan Kejuruan 2016, 23, 45-50. [CrossRef]

85. Dubickis, M.; Gaile-Sarkane, E. Transfer of Know-How Based on Learning Outcomes for Development of Open Innovation. J. Open Innov. Technol. Mark. Complex. 2017, 3, 4. [CrossRef]

86. JinHyo, J.Y.; Xiaofei, Z.; KwangHo, J.; Tan, Y. The Culture for Open Innovation Dynamics. Sustainability 2020, 12, 5076. [CrossRef]

87. Rexhepi, G.; Hisrich, R.D.; Ramadani, V. (Eds.) Open Innovation and Entrepreneurship; Springer: Cham, Switzerland, 2019; p. 126. ISBN 978-3-030-16911-4.

88. JinHyo, J.Y.; DongKyu, W.; KyungBae, P. Entrepreneurial cyclical dynamics of open innovation. J. Evolut. Econ. 2018, 28, 1151-1174. [CrossRef]

(C) 2020 by the authors. Licensee MDPI, Basel, Switzerland. This article is an open access article distributed under the terms and conditions of the Creative Commons Attribution (CC BY) license (http://creativecommons.org/licenses/by/4.0/). 